\title{
Public Credibility Drives Vaccination Decisions
}

Citation for published version (APA):

Penders, B. (2014). Public Credibility Drives Vaccination Decisions. Science, 344(6185), 693-693. https://doi.org/10.1126/science.344.6185.693

Document status and date:

Published: 16/05/2014

DOI:

10.1126/science.344.6185.693

Document Version:

Publisher's PDF, also known as Version of record

Document license:

Taverne

\section{Please check the document version of this publication:}

- A submitted manuscript is the version of the article upon submission and before peer-review. There can be important differences between the submitted version and the official published version of record.

People interested in the research are advised to contact the author for the final version of the publication, or visit the DOI to the publisher's website.

- The final author version and the galley proof are versions of the publication after peer review.

- The final published version features the final layout of the paper including the volume, issue and page numbers.

Link to publication

\footnotetext{
General rights rights.

- You may freely distribute the URL identifying the publication in the public portal. please follow below link for the End User Agreement:

www.umlib.nl/taverne-license

Take down policy

If you believe that this document breaches copyright please contact us at:

repository@maastrichtuniversity.nl

providing details and we will investigate your claim.
}

Copyright and moral rights for the publications made accessible in the public portal are retained by the authors and/or other copyright owners and it is a condition of accessing publications that users recognise and abide by the legal requirements associated with these

- Users may download and print one copy of any publication from the public portal for the purpose of private study or research.

- You may not further distribute the material or use it for any profit-making activity or commercial gain

If the publication is distributed under the terms of Article $25 \mathrm{fa}$ of the Dutch Copyright Act, indicated by the "Taverne" license above, 
LETTERS I BOOKS I POLICY FORUM | EDUCATION FORUM | PERSPECTIVES

\section{LETTERS}

\section{China's Soil Pollution: Farms on the Frontline}

CHINA'S SOIL POLLUTION IS MUCH WORSE THAN PREVIOUSLY THOUGHT ("CHINA GETS SERIous about its pollutant-laden soil," C. Larson, News \& Analysis, 28 March, p. 1415). A report released on 17 April admitted that $16.1 \%$ of the Chinese soil was polluted, including $19.4 \%$ of farmland, $10.0 \%$ of forest land, $10.4 \%$ of grassland, and $11.4 \%$ of unused land (1). Of the contaminated soil samples, $82 \%$ contained toxic inorganic pollutants, the most common being heavy metals such as cadmium, mercury, arsenic, chromium, and lead, which can cause chronic health problems. Moreover, levels of organic pollutants such as dichlorodiphenyltrichloroethane (DDT), polycyclic aromatic hydrocarbons (PAHs), and hexachlorocyclohexanes (HCHs) are also very high, and samples above established safety levels account for $1.9 \%$, $1.4 \%$, and $0.5 \%$, respectively, of all tested soil samples, which covered 6.3 million square kilometers. Aside from industrial plant waste and mining operations, the report states that the unsustainable use of chemical fertilizers and pesticides is a main human cause of widespread soil pollution (1).

China's food production is affected by soil pollution but also creates much pollution itself. China consumes nearly one-third of the world's fertilizer, and the pesticide usage per unit area is 2.5 times the world average (2). The quality of cultivated land should be guaranteed. Farmers should be subsidized to improve fertilizer use efficiency and encouraged to adopt organic and biodynamic farming methods that are not reliant on heavy input of chemicals. Soil remediation projects should be implemented to improve the polluted soil gradually. Finally, there is a need to change cultural habits relating to consumption so as to reduce food waste nationwide.

RUISHAN CHEN, ${ }^{1 *}$ ALEX DE SHERBININ, ${ }^{2}$ CHAO YE, ${ }^{3}$ GUOQING SHI ${ }^{1}$

${ }^{1}$ School of Public Administration, Hohai University, Nanjing, 210098, China. ${ }^{2}$ Center for International Earth Science Information Network (CIESIN), Columbia University, Palisades, NY 10964, USA. ${ }^{3}$ College of Geographic Sciences, Nanjing Normal University, Nanjing 210023, China.

*Corresponding author. E-mail: chenrsh04@gmail.com

\section{References}

1. Ministry of Environmental Protection and Ministry of Land and Resources of P.R. China, "Reports on China's Soil Pollution Survey" (2014); www.zhb.gov.cn/gkml/hbb/qt/201404/t20140417_270670.htm [in Chinese]

2. "Establish a long-term mechanism for sustainable agricultural development," China People's Daily (22 January 2014); http:// paper.people.com.cn/rmrb/htm//2014-01/22/nw.D110000renmrb_20140122_1-02.htm\#fin [in Chinese].

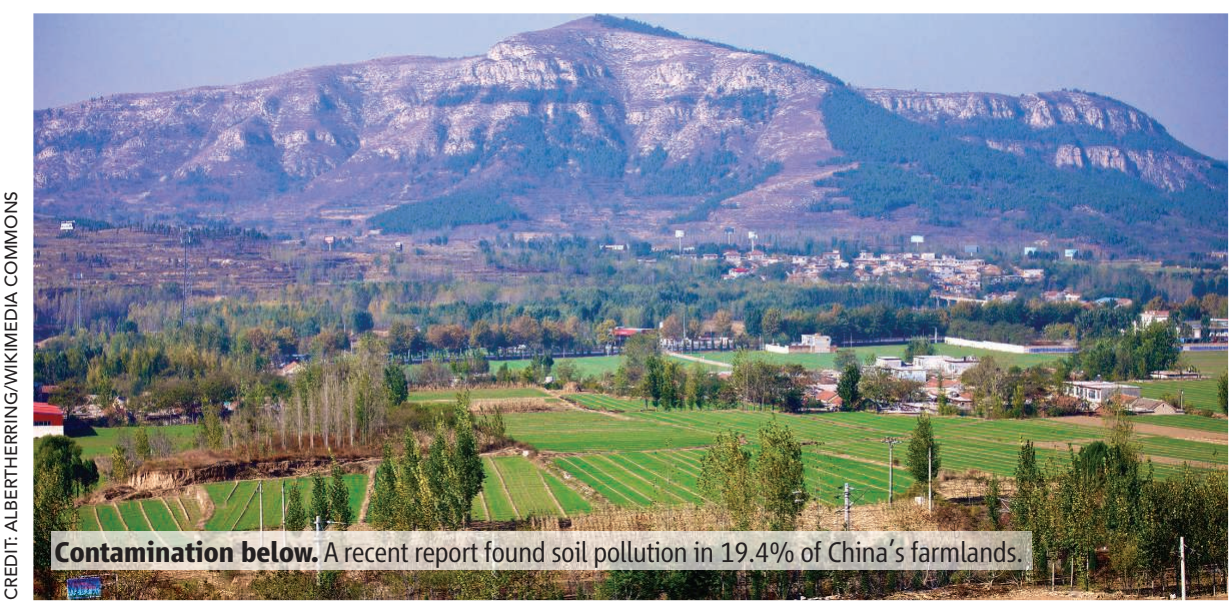

\section{China's Soil Pollution: Urban Brownfields}

CHINA'S PLANS TO TACKLE FARMLAND POLlution and improve food safety are to be welcomed ("China gets serious about its pollutant-laden soil," C. Larson, News \& Analysis, 28 March, p. 1415). However, the country faces equally serious urban soil and water pollution.

As a result of unparalleled urbanization over recent decades, many polluting and energy-intensive activities, including steel, coke, pesticide, and chemical industries, have relocated from urban areas to peripheral or rural areas (1). The legacy is more than 5000 brownfields - sites polluted, or potentially polluted, by hazardous substances - in China's major cities (2). A recently released ambitious urbanization plan will move more polluting plants from cities, leaving more brownfield sites (3). Brownfields pose health and environmental hazards in densely populated cities and are obstacles to urban and economic development. Soil concentrations of pollutants, including heavy metals, persistent organic pollutants, and benzene, can be hundreds of times the regulated limits (4). Seepage will also result in groundwater contamination.

Many brownfields have been used for housing. Without adequate survey and remediation of toxic brownfields, construction has already resulted in acute poisoning incidents. For example, workers were hospitalized during construction on sites at former pesticide factories in Beijing and Wuhan (4). Residents of newly built houses are often unaware of pollution beneath their properties. The Guangzhou Asia Games Village site was changed due to soil pollution from fertilizer factories, but housing for local people is being built in the area (5).

The Chinese Premier vowed to declare "war on pollution." However, government spending on environmental protection and energy conservation decreased by $9.7 \%$ between 2012 and 2013 (6). Funding and 
technology may limit remediation of Chinese brownfields, but information should be made publicly available to raise awareness and facilitate wider participation in brownfield management. Experience from elsewhere, such as the U.S. "Brownfield Act" (7), should be deployed to demonstrate commitment to tackling the growing problem of soil pollution.

HONG YANG, ${ }^{1 *}$ XIANJIN HUANG, ${ }^{2}$

JULIAN R. THOMPSON, ${ }^{3}$ ROGER J. FLOWER ${ }^{3}$

${ }^{1}$ Centre for Ecological and Evolutionary Synthesis, Department of Biosciences, University of Oslo, Blindern, 0316 ,

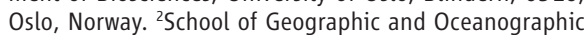
Science, Xianlin Campus, Nanjing University, Nanjing 210023, China. ${ }^{3}$ Wetland Research Unit/Environmental Change Research Centre, UCL Department of Geography, University College London, London, WC1E 6BT, UK.

*Corresponding author. E-mail: hongyanghy@gmail.com

\section{References}

1. H. Yang, R. J. Flower, J. R. Thompson, Nature 490, 342 (2012).

2. East Asia Infrastructure Division of the World Bank, China Waste Management: Problems and Suggestions (World Bank, 2005).

3. The Central People's Government of the People's Republic of China, 2014 (www.gov.cn/zhengce/ 2014-03/16/content_2640075.htm) [in Chinese].

4. M. jin, Ecol. Econ. 258, 18 (2012).

5. S. Gao, K. Wang, Caijing Mag. 323, 1 (2012).

6. Ministry of Finance of the People's Republic of China,
2014 (www.mof.gov.cn/zhengwuxinxi/caizhengxinwen/ 201403/t20140306_1052323.html) [in Chinese].

7. Y. Gong, International Experience in Policy and Regulatory Frameworks for Brownfield Site Management (World Bank, 2010).

\section{Scientific Justification} for Animal Capture

IN THE NEWS \& ANALYSIS STORY "COURT slams Japan's scientific whaling" (4 April, p. 22), V. Morell recounts the recent judgment of the International Court of Justice that the second Japanese scientific whaling program in the Antarctic (JARPA II) shall cease. This decision has given extra weight to a principle that is already contained in most existing scientific and ethical guidelines for research involving the taking of wild animals: Sample sizes (numbers of animals taken) must be justified in advance in relation to the specific objectives of the research.

Wisely, the court did not try to answer the broader question of what constitutes legitimate scientific research, but it faulted the absence of explanation or analysis as to how the specified numbers of whales to be caught would have contributed to the objectives of the JARPA II program. The ruling has implications for Japan's whaling program in the North Pacific (JARPN II). An Expert Panel appointed by the International Whaling Commission to review Japan's whaling in the North Pacific, which targeted up to 100 sei whales, 50 Bryde's whales, 220 minke whales, and 10 sperm whales a year (1), also noted the absence of a scientific justification for the number of whales killed in relation to quantifiable research objectives (2).

While not restricting the freedom of scientific research, the International Court of Justice ruling highlights the importance of careful analysis and clear justification of the study duration and of the sample sizes required to meet research objectives, in advance of any take of wild animals.

JUSTIN COOKE, ${ }^{1}$ VASSILI PAPASTAVROU, ${ }^{2}$ RUSSELL LEAPER, ${ }^{3 *}$ SIDNEY HOLT ${ }^{4}$

${ }^{1}$ Centre for Ecosystem Management Studies, Windenreute, 79312, Germany. ${ }^{2}$ Department of Biology, University of Bristol, Bristol, BS8 2LR, UK. ${ }^{3}$ School of Biological Sciences, University of Aberdeen, Aberdeen, AB24 2TZ, UK. ${ }^{4} \mathrm{VoC}$ Palazzetta 68, Paciano PG, 06060, Italy.

*Corresponding author. E-mail: r.c.leaper@abdn.ac.uk 


\section{References}

1. International Whaling Commission, J. Cetacean Res. Manage. 11 (suppl.), 405 (2010).

2. Government of Japan, "Revised research plan for cetacean studies in the western North Pacific under Special Permit (JARPN II)," Paper SC/56/01 presented to IWC Scientific Committee, Sorrento, Italy (2004).

\section{Public Credibility Drives Vaccination Decisions}

IN THEIR EDITORIAL "ADDRESSING VACCINE hesitancy" (25 April, p. 339), B. R. Bloom, E. Marcuse, and S. Mnookin identify a need to combat antivaccination messages with evidence-based strategies to best communio cate the importance of vaccination. "The crux 文 of the problem," they write, "is our inability to demonstrate to skeptical parents that vacciएutions save lives."

This inability is not due to a lack of evidence. Rather, it is a struggle between public health officials and vaccination skeptics for public credibility. Public debate is 立 frequently guided by particulars: singular cases and narratives of inexplicable deaths 㟧 or illness following vaccination. These par-

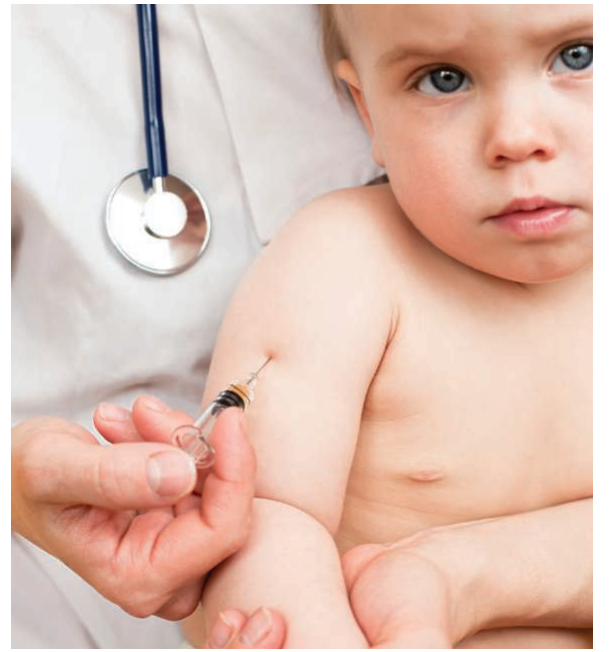

ticulars are delivered by voices that skeptical parents trust. A well-calibrated display of particulars allows many people to relate to such stories (1).

This suggests that public credibility is not the result of experts telling the truth as they see it. It is the result of a demonstrated ability to solve problems (2), to build trust amongst one's audience (3), and to take doubts seriously rather than rejecting them as ignorant
(4). After all, beyond the boundaries of the lab, trust and narratives contribute as much as truth and data to public credibility.

\section{BART PENDERS}

School for Public Health and Primary Care (Caphri), Maastricht University, Maastricht, 6200MD, Netherlands. E-mail: b.penders@maastrichtuniversity.nl

\section{References}

1. S. Shapin, in Public Science in Liberal Democracy, P. W. B. Phillips, Ed. (Univ. of Toronto Press, Toronto, 2007), pp. 33-39.

2. E. Freidson, Profession of Medicine: A Study of the Sociology of Applied Knowledge (Univ. of Chicago Press, Chicago, 1988).

3. E. v. Rijswoud, Nature 460, 571 (2009).

4. G. A. Poland, R. M. Jacobsen, N. Engl. J. Med. 364, 97 (2011).

\section{Letters to the Editor}

Letters ( $\sim 300$ words) discuss material published in Science in the past 3 months or matters of general interest. Letters are not acknowledged upon receipt. Whether published in full or in part, Letters are subject to editing for clarity and space. Letters submitted, published, or posted elsewhere, in print or online, will be disqualified. To submit a Letter, go to www.submit2science.org. 


\section{Science}

\section{Public Credibility Drives Vaccination Decisions}

Bart Penders

Science, 344 (6185),

View the article online

https://www.science.org/doi/10.1126/science.344.6185.693

Permissions

https://www.science.org/help/reprints-and-permissions 